\title{
CSR marketing outcomes and branch managers' perceptions of CSR
}

\author{
Miguel Angel Moliner, Diego Monferrer Tirado and \\ Marta Estrada-Guillén \\ Department of Business Administration and Marketing, \\ Universitat Jaume I, Castellón de la Plana, Spain
}

Received 6 November 2018

Revised 5 March 2019

4 April 2019

Accepted 17 April 2019

\begin{abstract}
Purpose - The purpose of this paper is to analyze the role of bank branch managers' perceptions of corporate social responsibility (CSR) in CSR marketing outcomes.

Design/methodology/approach - The paper proposes a causal model establishing that managers' perceptions of CSR influence the perception of CSR held by the branch's customers, which in turn directly affects customer satisfaction, customer trust, customer engagement and customer loyalty. The unit of analysis in this quantitative study is the bank branch. Two questionnaires were administered: one to branch managers and another to five customers in each branch.

Findings - Branch managers' perceptions of CSR have a marked influence on customers' perceptions of CSR, which again have a notable impact on the relationship variables studied: customer satisfaction, customer trust, customer engagement and customer loyalty.

Research limitations/implications - The sample was taken from two banks in the same country (Spain) and only five customers were interviewed in each branch. The type of customers analyzed should be taken into account since a growing number of customers now carry out all of their banking online and are less likely to visit their branch.

Practical implications - The results highlight the importance of adopting socially responsible actions not only in the bank as a whole, but also in individual branches. It would, therefore, seem crucial for high level bank executives not only to involve branch managers in the bank's CSR strategy, but also to empower them to undertake CSR actions that involve the customers and local community with which they interact.

Originality/value - First, the paper reveals the differences within the same organization in the way its CSR strategy is implemented. Second, intermediary figures or supervisors are shown to have a key role in ensuring the organization's CSR strategy is effective. Third, the study emphasizes the importance of customers' perception of CSR in achieving the main outcomes of relationship marketing (satisfaction, trust, engagement and loyalty). Fourth, the methodology applied in the study is innovative in its construction of dyads in which the branch is the unit of analysis, enabling a comparison between the manager's perceptions of CSR with that of five customers from the same branch. Fifth, the findings add to the knowledge of a particularly relevant sector in the recent economic crisis, namely, the retail banking industry.
\end{abstract}

Keywords CSR branch manager, CSR customer, CSR marketing outcomes, Retail banking industry

Paper type Research paper

\section{Introduction}

In the last decade, interest in corporate social responsibility (CSR) has spread widely in banking industry and among academics (Aguinis and Glavas, 2012; Chomvilailuk and Butcher, 2013; Pérez and Rodríguez, 2014; Carroll, 2015, 2017; Khan et al., 2015; Jaiyeoba et al., 2018;

(C) Miguel Angel Moliner, Diego Monferrer Tirado and Marta Estrada-Guillén. Published by Emerald Publishing Limited. This article is published under the Creative Commons Attribution (CC BY 4.0) licence. Anyone may reproduce, distribute, translate and create derivative works of this article (for both commercial and non-commercial purposes), subject to full attribution to the original publication and authors. The full terms of this licence may be seen at http://creativecommons.org/licences/by/4.0/legalcode

The authors gratefully acknowledge the financial support provided by the Spanish Ministry of Economy and Competitiveness via the research project "La confianza del consumidor respecto a la calidad de la relación y la orientación al mercado de las entidades financieras: los efectos de la crisis" (ECO2013-47134-P).

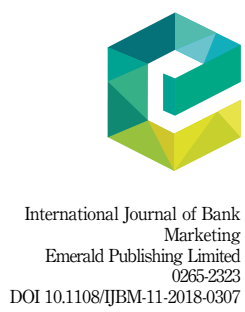


Pratihari and Uzma, 2018). The banking industry was heavily implicated in the origins of the last crisis by marketing complex high-risk products to people who were unable to assess their implications (Aguinis and Glavas, 2012; Carroll, 2015; Jaiyeoba et al., 2018). Financial companies have been forced to strategically rearm, adopting CSR policies that not only prevent the repetition of the recent cases of irresponsibility, but also rebuild their image and reputation through the adoption of ethical principles and a commitment to improving the banking environment. In this new competitive framework, financial institutions must be seen as actively protecting the environment, looking after their employees, conducting their business in an ethical manner and cultivating their image as contributors to the welfare of society (Jaiyeoba et al., 2018). CSR has, therefore, become a major aspect of banks' corporate identity and a key competitive differentiator. Financial institutions are investing heavily in projecting a differentiated image to their stakeholders by promoting socially responsible practices and strengthening their ethical dimension internally (Chomvilailuk and Butcher, 2013; Khan et al., 2015; Pérez and Rodríguez, 2017; Jaiyeoba et al., 2018; Pratihari and Uzma, 2018).

In the last decade, academic analysis of the effects CSR actions have on customers' attitudes and behavior has burgeoned in the literature on CSR in the banking industry (Khan et al., 2011; Bravo et al., 2012; Pérez and Rodríguez, 2012, 2017; Krasodomska, 2015; Kilic, 2016; Pratihari and Uzma, 2018). However, little attention has been paid to the complexity of bank-customer relationships. Banks have extensive networks of branches where their products are sold and their customers attended. While this presence in territorial regions allows them to personalize their services, it is also an obstacle to quality standardization (Maignan et al., 2005). Each branch has its own manager and staff who are responsible for achieving the targets established by the company. It is at the branch level that interactions between customers and employees take place, and the branch is the basis for customers' trust in the brand, and their evaluations of service quality, the ethics of the institution and the degree to which their expectations are met (Pérez and Rodríguez, 2014). It is also at the branch level that the institution can undertake a large number of social and environmental activities which provide an opportunity to strengthen emotional bonds with its customers. Hence, bank branch employees not only observe, but they influence the organization's uses and practices of the strategy by lending credibility to its value proposal (Rego et al., 2011).

However, the academic literature has neglected the role of the branch and branch managers in banks' CSR strategies (Ramus and Steger, 2000; Aguinis and Glavas, 2012). It is our view that branch managers play an essential role, since they must reconcile pressure to meet the commercial goals set by corporate headquarters with the principles of CSR. El Akremi et al. (2018) contend that employees are interested in, contribute to, perceive, evaluate and react to the CSR activities their firms implement. One of the central aspects of employee reactions is the perception employees have of these CSR activities. Based on agency theory, Oh et al. (2018) consider that executives pursue their own interests, unless they are properly monitored or an appropriate incentive system is put in place. However, because these two governance systems are usually designed to meet financial targets, much remains unclear about branch managers' motivations to promote the bank's CSR actions. The guidelines branch managers set out for their teams - customer contact employees - are central to the implementation and success of the CSR strategy.

The question posed in the present study is: What is the role played by bank branch managers' perceptions of CSR in CSR marketing outcomes? More specifically, we ask two research questions:

$R Q 1$. How do bank branch managers' perceptions of CSR influence the bank customers' perceptions of CSR?

$R Q 2$. How do the bank customers' perceptions of CSR influence their satisfaction, trust, engagement and loyalty? 
To respond to these questions we carried out a literature review, from which five hypotheses were formulated. Two questionnaires were then designed, based on contributions from the literature, to test these hypotheses. The first questionnaire was administered to a sample of branch managers employed in one of Spain's major banks, and the second, to a sample of the bank's customers. The unit of analysis in the study was the bank branch, for which dyads were constructed combining the branch manager's perception with the average perception of five customers from the same branch. Structural equation models (SEM) were used to obtain the results.

\section{Conceptual framework}

\subsection{The concept of CSR and stakeholder theory}

There is a lack of consensus on the definition of CSR in the literature (Pratihari and Uzma, 2018). The philosophical view of CSR has evolved since its first appearance in the 1950s (Carroll, 2015). Today, CSR is broadly understood as the role a company plays in society, taking into account all the moral obligations that maximize the positive impact and minimize the negative impact it has on its surroundings (Maignan and Ferrell, 2001; García et al., 2005). El Akremi et al. (2018) recently defined CSR as "an organization's context-specific actions and policies that aim to enhance the welfare of stakeholders by accounting for the triple bottom line of economic, social and environmental performance" (p. 623). CSR is therefore associated with ethical behavior in the firm that is not only manifested in responsible economic, social and environmental actions, but must permeate all of the firm's business decisions and behaviors. Scholars have attempted to classify CSR activities or actions on this basis; some authors do so in terms of stakeholders (McDonald and Rundle-Thiele, 2008; Bravo et al., 2012; Pérez and Rodríguez, 2012, 2017; Krasodomska, 2015), whereas others focus on CSR activities (Narwal, 2007; Khan et al., 2011; Kilic, 2016; Pratihari and Uzma, 2018).

It is our view that the two approaches to the dimensionality of CSR are complementary and can help to further understanding of the concept. Stakeholder theory is a key approach for investigating the scope and consequences of a company's CSR strategy (Freeman, 1984; Aguinis and Glavas, 2012). Freeman (1984) and El Akremi et al. (2018) hold that a firm should be concerned about all the groups or individuals that are or could be affected, directly or indirectly, by the pursuit of its objectives. From this perspective, the stakeholders are the main targets of CSR, which is regarded as a set of economic, social, and environmental activities that the firm undertakes to fulfill its obligations to each one of these groups (Carroll, 2006; Khan et al., 2015; El Akremi et al., 2018). Pratihari and Uzma (2018) consider that CSR initiatives should be designed to help all stakeholders achieve their personal objectives and to establish firm emotional bonds with them. Barnett (2007) considers that the capacity of CSR to create value for the firm lies in its ability to generate positive relationships with its stakeholders (Bhattacharya et al., 2009; Peloza, 2009).

Stakeholders are classified as external and internal, voluntary and involuntary, and primary and secondary (Turker, 2009). El Akremi et al. (2018) designed a scale to measure the employee's perception of CSR that identifies five stakeholder groups: employee-oriented CSR, local community-oriented CSR, supplier-oriented CSR, customer-oriented CSR and shareholderoriented CSR. In a similar vein, Pérez and Rodríguez (2014) included four stakeholder groups in their evaluation of CSR in the banking industry: customer-oriented CSR, shareholder- and board of directors-oriented CSR, employee-oriented CSR, and society-oriented CSR. CSR oriented toward customers includes the comprehensive and honest communication of products and services, and the management of customer complaints. CSR oriented toward shareholders and the board of directors includes information transparency and pursuit of economic profit. CSR oriented toward employees covers aspects related to job creation and promotion opportunities. CSR oriented toward society refers to areas such as charitable activities, community development and protection of the natural environment. 
Marketing scholars have tended to focus on the main primary stakeholders: customers and channel members (Maignan and Ferrell, 2004). However, stakeholder research suggests that customers and employees have the greatest influence on firms' results (Berman et al., 1999; Maignan et al., 2005). The present study is grounded on the hypothesis that in the context of a bank with branches distributed across a territory, the perception of CSR in each branch will influence its customers' perceptions of CSR (El Akremi et al., 2018). Therefore, branch managers and the guidelines they convey to their team play a vital role in customers' perceptions of CSR.

\subsection{Customers' and branch managers' perceptions of CSR}

Several studies have analyzed the effects of employees' perceptions of corporate CSR strategy on organizational attractiveness to prospective employees (Greening and Turban, 2000), employee justice perceptions (Rupp et al., 2006), organizational commitment (Peterson, 2004; Rupp et al., 2006; Brammer et al., 2007), identification with the company (Berger et al., 2006; Rodrigo and Arenas, 2008), job satisfaction (Herrbach et al., 2004; Valentine and Fleischman, 2008), performance of sales staff (Larson et al., 2008) and employee loyalty (Bhattacharya et al., 2008, 2011). Rego et al. (2011) find few studies exploring the way members of an organization develop attitudes and behaviors in line with their perceptions of the organizations they belong to. Bhandarker (2003), Chahal and Sharma (2006) and El Akremi et al. (2018) consider that the positive role played by human resources is important for socially responsible organizations. According to stakeholder theory, a company interacts with its primary and secondary stakeholders, and through CSR activities, fosters goodwill among those groups and builds stronger relationships with them (Rodrigo and Arenas, 2008; Kim et al., 2010; Du et al., 2015; El Akremi et al., 2018).

Branch managers and employees are internal stakeholders that the company must convince and persuade to engage with its strategy and act in accordance with it (Maignan and Ferrell, 2001; Kaler, 2009). Branches play a critical role in shaping customers' perceptions of a company's CSR and in the extent to which their expectations are met (Pérez and Rodríguez, 2014). In this vein, Maignan et al. (2005) advocate evaluating a company's commitment to CSR at the individual business unit level, since each business unit in a large corporation can approach issues related to its stakeholders in different ways. In other words, levels of customer orientation and commitment to CSR can vary within the same organization. At the marketing strategy level, firms must convince customers not only through CSR interventions but also by showing that in moments of truth, corporate values are coherent with those of their customers.

Some studies have examined the influence of branch managers' commitment to CSR on the development and implementation of creative environmental ideas by employees (Ramus and Steger, 2000) or on employees' initiatives that bring about more positive company action (Aguinis and Glavas, 2012). However, no studies have to date examined the relationship between employees' and customers' perceptions of CSR by studying the influence of the context in which the service interaction takes place.

Oh et al.'s (2018) study analyzed the influence governance mechanisms have on the implementation of CSR in a firm. Agency theory holds that company executives pursue their own interests without taking into account those of other stakeholders, unless they are properly monitored or an appropriate incentive system is in place. These two governance systems lead to improved financial outputs (Eisenhardt, 1989; Jensen and Meckling, 1976), but it remains unclear whether they also enhance nonfinancial social outcomes, such as CSR.

The importance of the branch manager rests on their power and legitimacy (Mitchell et al., 1997; Maignan et al., 2005). A bank branch manager's power arises from their ability to impose their will on the employees in their team, whereas legitimacy is generated by the legal support the manager has, as formalized in the organizational structure of the company, which enables them to take on responsibilities and exercise power (Mitchell et al., 1997). This person, 
therefore, is a key intermediary figure that plays no part in designing the organization's CSR CSR marketing strategy but is responsible for implementing it.

Although Oh et al's (2018) study centers on the strategic angle, some of their considerations appear to be applicable to branch managers. According to agency theory, branch managers pursue their own interests. The monitoring they are subject to and the incentives systems are based on their achievement of financial outcomes. However, the CSR strategy promoted at the corporate level must, in certain aspects, be implemented at the branch level. The perception of CSR held by branch managers or mid-level managers will influence branch employees' visions and customers' perceptions of the initiative, and will encourage branches to implement organizational citizenship behaviors (El Akremi et al.,2018).

Lindgreen and Swaen (2010) argue that managers' involvement and building bridges with stakeholders through formal and informal dialogue and engagement practices are essential to the successful implementation of a CSR strategy. Bank branch managers should attempt to set targets aligned with those of their customers and convince them to accept the organization's strategy (Andriof and Waddock, 2002). The branch managers' perception of CSR is therefore a key factor in conveying the CSR strategy in a company's branches, and in cultivating positive perceptions of CSR among their customers:

H1. Bank branch managers' perceptions of CSR positively influence their customers' perceptions of CSR.

\subsection{CSR outcomes and customers' perceptions of CSR}

From the theoretical perspective, consumers expect firms to be coherent with social values as part of their contribution to society (Maignan et al, 2005). In a study of the banking sector, Pérez and Rodríguez (2013) conclude that when the products and services offered by competing firms are highly standardized, CSR strategy is a useful differentiation tool. Tinker and Banner (2017) found that almost 70 percent of their sample of Australian bank customers was influenced by the bank's CSR program when choosing a financial product or service.

Pérez and Rodríguez (2017) propose a hierarchy-of-effects approach to explain how customers' perceptions of CSR influence their affective and conative responses in a banking context. Their proposal is based on the thesis that the customer's decision-making process passes through several stages following a cognitive-affective-conative sequence. According to these authors, "CSR perceptions are understood as a set of beliefs (i.e. cognitive stage) that trigger customer affective responses (i.e. affective stage) that, in turn, affect customer behaviours (i.e. conative stage)." In a comprehensive review of the CSR literature, Aguinis and Glavas (2012), Khan et al. (2015) and Pérez and Rodríguez (2017) found few studies associating customers' perceptions of CSR with perceptions and intentions such as satisfaction, consumer-organization fit or trust. Following the hierarchy-of-effects approach we selected four affective and conative responses: satisfaction, trust, engagement and loyalty.

2.3.1 CSR perceptions and satisfaction. Customer satisfaction is "a judgement that a product or service feature, or the product or service itself, provided a pleasurable level of consumption-related fulfilment including levels of under or overfulfillment" (Oliver, 1999). Customers' perceptions of CSR positively influence their satisfaction with the company. Luo and Bhattacharya (2006) find three research streams that explain this relationship. First, because consumers are not simply economic beings but are part of a family, a community and a country, they will therefore be more satisfied with socially responsible products and services (Daub and Ergenzinger, 2005). Second, CSR initiatives are a key factor in inducing consumers to identify with the firm, for which they must be satisfied with the company's offer (Bhattacharya and Sen, 2003). Third, CSR forms part of the perceived value of a company, which is an antecedent of consumer satisfaction (Mithas et al., 2005). In addition, expectations are fundamental to customer satisfaction, and in general, customers expect 
companies to behave responsibly (Pérez and Rodríguez, 2014). If there is any suspicion about the legal and/or ethical behavior of a financial institution, even when the service provided is technically satisfactory, the customer will not be wholly satisfied because their expectations of the CSR action are unfulfilled. The CSR-satisfaction relationship has been empirically tested in previous studies (Luo and Bhattacharya, 2006; He and Li, 2011; Cheung et al., 2015; Saeidi et al., 2015; Ashraf et al., 2017; Pérez and Rodríguez, 2017):

H2. Customers' perceptions of CSR positively influence their satisfaction with the company.

2.3.2 CSR perceptions and trust. El-Manstrly et al. (2011) define trust as a function of the perceived reliability and integrity of a brand or service provider. Customer trust implies customer familiarity and comfort with a service provider that should reduce the customer's feelings of anxiety. It is inversely related to the provider's opportunistic behaviors and combines moral considerations (integrity, honesty, benevolence, deontology, ethics, etc.) with calculated judgments such as ability to meet expectations, competence or know how (Aurier and N'Goala, 2010).

Customer trust is a key element for the supplier to be able to maintain long-term relationships (Kantsperger and Kunz, 2010; Aurier and N'Goala, 2010). In service industries, like retail banking, trust becomes crucial in many relational exchange situations and reduces anxiety over the service outcome (Dimitriadis et al., 2011; Khan et al., 2015).

Customers' perceptions of CSR affect their trust in the company. Khan et al. (2015) regard trust as a central element in long-term relationships between a company and its customers, but the relationship between CSR and trust has yet to receive sufficient analysis in the literature. Trust is particularly important in relationships where risk and involvement are high, the banking industry being a clear example (Khan et al., 2015). According to Fatma et al. (2015), consumers have a high level of trust in companies that are perceived to be socially responsible. From the theoretical perspective, CSR customer perception has a direct impact on the emotional and moral dimensions of trust: integrity, honesty, benevolence, deontology or ethics (Lamberti and Lettieri, 2009; Aurier and N'Goala, 2010). CSR activities transmit information about the company's corporate values and allow the customer to associate the company's personality with the moral dimension of trust, lending it credibility and strengthening the brand's positioning (Swaen and Chumpitaz, 2008; Martínez and del Bosque, 2013). Lin et al. (2011) have shown that investment in CSR leads to a recovery of credibility following a product or company crisis. Stanaland et al. (2011) find that customers have greater trust in socially responsible companies. The relationship between CSR and trust has been empirically tested in various studies (Swaen and Chumpitaz, 2008; Martínez and del Bosque, 2013; Khan et al., 2015; Fatma et al., 2015; Ashraf et al., 2017) but according to Khan et al. (2015), deeper knowledge about this causal relationship is needed in order to generalize the conclusions:

H3. Customers' perceptions of CSR positively influence their trust in the company.

2.3.3 CSR perceptions and engagement. The concept of engagement originated in the psychology of human resources to explain employees' undertaking of tasks that go beyond their contractual obligations (Hollebeek, 2011; Saks and Gruman, 2014). Sprott et al. (2009), Van Doorn et al. (2010), Hollebeek (2011), Brodie et al. (2011), Kumar et al. (2013) and Hollebeek and Chen (2014) all point out that customer engagement is a psychological state and an emotional bond generated by the experiences with a brand or a firm: that is, engaged partners have a more satisfactory relationship and a strong emotional bond.

Pansari and Kumar (2017) describe the process by which engaged customers are generated. A brand's marketing activities raise awareness among customers about its products and services, which helps the customer to understand what the company is offering and triggers the desire to purchase. When a customer makes a purchase, he or she 
has an experience, which may be positive or negative, which arouses certain emotions about the brand or company and a level of satisfaction with it (Verleye, 2015; Cambra-Fierro et al., 2016). If their experience arouses positive satisfaction, customers will be more likely to repurchase, and if their emotions are positive they should lead to non-transactional behaviors (Verhoef et al., 2010; Klaus et al., 2013; Chahal and Dutta, 2015).

Customers' perceptions of CSR influence their engagement with the company (Mandhachitara and Poolthong, 2011). CSR activities are part of the value offer and the identity of the company, and stimulate the customer to purchase. If the CSR strategy generates positive feelings toward the company, customers are able to establish an emotional bond or engagement (Lindgreen and Swaen, 2010; Mandhachitara and Poolthong, 2011; Pérez and Rodríguez, 2013):

H4. Customers' perceptions of CSR positively influence their engagement with the company.

2.3.4 CSR perceptions and attitudinal loyalty. Customers' perceptions of CSR affect their loyalty to the company (Mandhachitara and Poolthong, 2011). A CSR strategy generates a favorable disposition toward a company or brand. He and Li (2011) showed that customer loyalty increases, the greater the firms' attention to CSR and service quality. A CSR strategy affects customers emotionally in that they feel more connected to the organization, which leads to stronger support for the company's strategy and greater loyalty (Pérez and Rodríguez, 2013; Chomvilailuk and Butcher, 2013). Stanaland et al. (2011) found that perceived CSR positively impacts customer loyalty. Khan et al. (2015) contend that CSR is becoming a critical factor in extending a company's loyal customer base. Walsh and Bartikowski (2013) found that CSR positively influences loyalty behavior in a German study, but that the same relationship was not significant in a US sample. Other studies have found a direct relationship between customer perception of CSR and loyalty (Maignan and Ferrell, 2001; Sureshchandar et al., 2001, 2002; Pirsch et al., 2007; Du et al., 2007; Mandhachitara and Poolthong, 2011; Pérez et al., 2013; Cheung et al., 2015; Ashraf et al., 2017):

H5. Customers' perceptions of CSR positively influence their loyalty to the company.

Figure 1 shows the model to be analyzed.

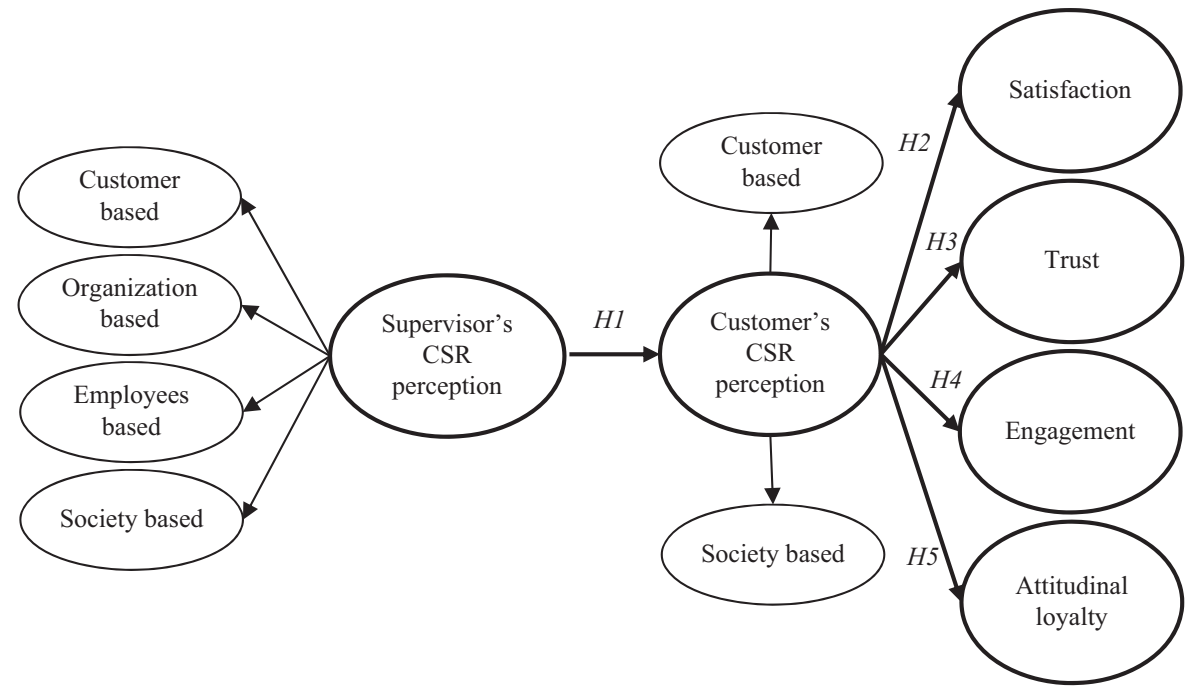

Figure 1. Model of effects 


\section{Study approach and research method}

\subsection{Data collection and sample}

The research team entered into a collaboration agreement with a major Spanish bank (one of the top five companies in terms of total assets according to Moody's international rating agency), which enabled us to interview both branch managers and their customers for this study. The research universe was 530 bank branches in four Spanish provinces: Castellón, Valencia, Alicante and Murcia.

The 2008 financial crisis hit the southern part of the European Union especially hard, and particularly the banks in Spain, which in October 2011 received a bailout from the European Union for up to $€ 1 \mathrm{bn}$. The enormous volume of negative news on this sector has severely eroded citizens' trust in banks since 2008. Although the problem of trust has spread across the whole western banking industry, the case of Spain may be the most paradigmatic. In response to this loss of trust, over the last five years the large Spanish banks have launched campaigns aimed at enhancing their reputations, largely by promoting CSR through their respective foundations. The intention behind this corporate strategy is to associate the brand's name with positive social and environmental aspects.

The conceptual integration of bank manager and customer perceptions in this study favored a two-sample research design with two separate questionnaires. The first one measured the managers' evaluation of CSR in their branches. The second questionnaire captured customers' CSR perceptions of their bank branches, and their satisfaction, trust, engagement and loyalty with them.

To ensure the questionnaires closely matched the reality in the firm, group activities were initially carried out with the bank's senior marketing managers, including discussions on the role of physical branches in guaranteeing banks' CSR, also aimed at identifying the key factors that could be strengthened at the branch level to meet this aim. The study's theoretical approach was therefore agreed and confirmed at first hand from the business perspective.

Following Ye et al.'s (2007) recommendations on questionnaire design, careful attention was paid to question order so as to avoid presenting the constructs in the order set out in our hypotheses (antecedents $\rightarrow$ mediating variables $\rightarrow$ consequences). The questionnaire items were also pre-tested through 10 and 15 personal interviews with bank branch managers and customers, respectively, in February 2015. This procedure helped to improve the wording of some of the questionnaire items, and ensure the terminology and language were easily understood by the respondents, and that the form, layout, sequence difficulty, length of the questionnaires and completion time were appropriate.

Prior to the fieldwork, the bank management informed personnel that university researchers would carry out a survey of managers and customers. Confidentiality was assured for the process of disseminating the results since data would be aggregated. Then managers and customers were interviewed by a team of researchers in fieldwork carried out between April and July 2015. The managers were interviewed in their offices and randomly chosen customers (five customers per branch) were interviewed while they were waiting to be attended. Only regular branch customers were included in the sample.

In both fieldwork studies, we used professional interviewers to ensure that the interviews followed a standard structure, and to guarantee that respondents understood the exact meaning of all the questions. Moreover, following Hox (1994) we used the intraclass correlation coefficient (ICC) to avoid significant interviewer effect in the results. The ICC results were close to 0.031 , as recommended by the literature for face-to-face surveys (Groves, 2004; Davis et al., 2010; Tortosa et al., 2015).

The response rate in the managers' sample was 42.45 percent (225 out of 530 branches). Of the total responses received, 17 were from branches in the province of Castellón, 49 in Valencia, 115 in Alicante and 44 in Murcia. The average number of employees per bank 
branch was between five and six (59.2 percent of the branches had between two and five employees; 34.5 percent between six and ten employees, and only 6.3 percent had more than ten employees). Finally, by branch type, 63 were firmly established branches (28.1 percent), 73 were in small locations (32.4 percent), 34 were in medium-sized locations (14.8 percent), 31 were in urban locations (13.8 percent) and 24 were branches for foreign customers (10.7 percent).

The second sample comprised 1,125 customers, 540 women (48 percent) and 585 men (52 percent), with an average age of 47 (15 percent between 18 and 29 years; 20 percent between 30 and 39 years; 21 percent between 40 and 49 years; 19 percent between 50 and 59 years; and 14 percent between 60 and 69 years). These profiles were comparable to the total population of customers in the branches analyzed.

Codification was used to identify and match the results of the two questionnaires, completed by each manager and the five customers. The unit of analysis was the branch manager-customer relationship; the research hypotheses were therefore tested on 225 dyads that associated each branch manager with the average of the five customers in the sample that he or she had attended. The ordinal nature of the customer variables was maintained in the calculations by rounding the average scores to eliminate decimals. This aggregation is consistent with previous suggestions (Yoon and Suh, 2003) that data should be collected at the level of analysis at which it will be aggregated. However, as Schneider and Bowen (1985) note, it is necessary to ensure that customers' ratings are reasonably stable within each service encounter. To test consistency or agreement across customers' responses on their perceptions of CSR in the branch (customer and society based), and their satisfaction, trust, engagement and loyalty with it, we estimated within-group interrater agreement for these constructs (James, 1982).

The average within-group interrater reliability values, $r_{w g(j)}$, for those constructs were $0.73,0.71,0.81,0.78,0.72$ and 0.80 , respectively, higher than the commonly accepted threshold of 0.7, suggesting sufficient within-group agreement to aggregate the data at branch level. We also used ICC statistics, ICC (1) and ICC (2) to assess interrater reliability (Batko, 1976) among the branch managers. The ICC (1) values were 0.28, 0.26, 0.30, 0.32, 0.27 and 0.32 for customers' CSR perceptions of the branch (customer and society based), and their satisfaction, trust, engagement and loyalty with it, respectively, much higher than the cutoff value of 0.12 (James, 1982), indicating a sufficient variability ratio. The ICC (2) values were $0.69,0.66,0.70,0.73,0.68$ and 0.73 , respectively, higher than the cutoff point of 0.60 (Glick, 1985), rendering sufficient interrater reliability among branch managers. In sum, all these results justify aggregating the data by customers at the manager level.

\subsection{Measurement instruments}

The construct of branches' CSR was measured with an adaptation of the scale developed by Pérez and Rodríguez (2013). This scale uses four dimensions to gather the CSR construct: customer (five items), organization (three items), employees (four items) and society (four items).

In turn, customers' CSR perceptions of their bank branches were measured using an adaptation of the scales proposed by Ha et al. (2014) and Liu et al. (2014). This scale had two four-item dimensions: customer and society.

We used an adaptation of the scale proposed by Bloemer and Odekerken (2002) to measure satisfaction, and the two scales developed by Camarero et al. (2005) to measure trust and attitudinal loyalty. The three are five-item scales.

Finally, to measure the level of customers' engagement with their branch, we adapted the four-item scale proposed by Blasco (2014) to the bank branch environment. Blasco's scale drew on previous contributions from Medlin and Green (2009) and Sprott et al. (2009).

Both questionnaires consisted of closed questions with items measured on a five-point Likert scale, where 1 represented the lowest agreement with the statement, and 5 the highest. For the translation of the measurement instrument from English into Spanish, the 
widely used back-translation method proposed by Brislin (1970) was followed in order to ensure the items were comparable to other language versions of the scale. Two bilingual professionals were thus employed, one to translate from the English source to Spanish and the other to provide a blind translation of this first translation back to English (without reading the original source text). When the two English versions were compared, the bilingual professionals verified that they were practically identical, suggesting that the Spanish version resulting from the process was equivalent to the English forms.

Table I summarizes the information on the sources of the measurement scales used in the study, the items of which are presented in Table II.

\subsection{Validity and scale reliability}

Confirmatory factor analysis was run using SEM to refine the scales with version 6.1 of the EQS multivariate software package. The maximum likelihood approach was followed to estimate the parameters.

First, we checked for signs of multicollinearity by testing the variance inflation factor among latent variables in our proposed overall model. Values were below 10 (Hair et al., 2010), suggesting multicollinearity was not an issue in our study. Additionally, we performed a one-factor test among latent variables in the proposed model to rule out common method data collection bias (Podsakoff et al., 2003; Friedrich et al., 2009). The overall fit was significantly poorer than the results of the confirmatory factor analysis with the study's proposed factor structure. These results imply that a single factor poorly reflects the data, indicating the possible absence of any common method bias the data collection (Farrell and Oczkowski, 2009).

Then we followed a model development strategy (Hair et al., 2010). Based on latent variable structures assumed for the different constructs, an improvement procedure was carried out to refine the initial models by suppressing the least appropriate indicators. Following Jöreskog and Sörbom's (1993) recommendations, first we examined the estimation parameters. Indicators were withdrawn if they did not fulfill the strong convergence condition, if they had individual standardized coefficients $(\lambda)$ under 0.6 , or had an average value of the standardized factor loadings below 0.7 (Bagozzi and Youjae, 1988; Steenkamp and Van Trijp, 1991; Hair et al., 2010). Compliance with the weak convergence condition was then verified (Steenkamp and Van Trijp, 1991) by analyzing the significance of the factor regression coefficients between indicators and their corresponding latent variables. To do this we revised the Student $t$-value by imposing the maximum requirement $(t>2.58$; $P=0.01)$. Finally, evolution of the main model fit measurements was monitored as the indicators were removed. Through this process the indicator LOY.3 from the attitudinal loyalty scale was eliminated as it did not meet the strong convergence condition (with a standardized coefficient $(\lambda)$ of 0.463 ). Removing this indicator does not affect the conceptual essence of the constructs considered.

Several tests were then run to verify whether the refinement process following the previous tests had negatively affected scale reliability. Internal consistency was tested with

Table I.

Sources of measurement scales used in this study

\begin{tabular}{llccc}
\hline Variables & References & Dimensions & Items & Scale \\
\hline Supervisor CSR perception & Pérez and Rodríguez (2013) & 4 & $16(5 ; 3 ; 4 ; 4)$ & Likert 5 points \\
Customer CSR perception & Ha et al. (2014), Liu et al. (2014) & 2 & $8(4 ; 4)$ & Likert 5 points \\
Satisfaction & Bloemer and Odekerken (2002) & 1 & 5 & Likert 5 points \\
Trust & Camarero et al. (2005) & 1 & 5 & Likert 5 points \\
Engagement & Blasco (2014) & 1 & 4 & Likert 5 points \\
Attitudinal loyalty & Camarero et al. (2005) & 1 & 5 & Likert 5 points
\end{tabular}


Supervisor perception of $C S R(C R=0.96 ; A V E=0.85)$

Customer-based $(\alpha=0.947 ; \mathrm{CR}=0.95 ; \mathrm{AVE}=0.79)$

CSR1.CUS1: established procedures are in place in this branch to respond to all customer complaints

CSR1.CUS2: we behave honestly with our customers

CSR1.CUS3: our employees provide customers with full information about the company's products

CSR1.CUS4: we endeavor to get to know our customers and their needs

CSR1.CUS5: we respect our customers' privacy (personal data)

Organization based $(\alpha=0.929 ; \mathrm{CR}=0.93 ; \mathrm{AVE}=0.82)$

CSR1.ORG1: we always aim to maximize our profits in this branch

CSR1.ORG2: we aim to secure our long-term success and outcomes

CSR1.ORG3: our managers have access to information on the economic position of our branch

Employees-based $(\alpha=0.941 ; \mathrm{CR}=0.94 ; \mathrm{AVE}=0.80)$

CSR1.EMP1: we are concerned about our employees' job security in this branch

CSR1.EMP2: we treat our employees fairly (without discrimination or abuse)

CSR1.EMP3: we encourage a pleasant working environment in this branch

CSR1.EMP4: we try to keep our employees motivated

Society based $(\alpha=0.920 ; \mathrm{CR}=0.92 ; \mathrm{AVE}=0.75)$

CSR1.SOC1: in this branch we are aware of the social problems in the locality

CSR1.SOC2: we believe we perform a role in the community that goes beyond generating profits

CSR1.SOC3: in this branch we are committed to improving the well-being of the neighborhood/city in which we operate

CSR1.SOC4: we have measures in place to protect the general environment (recycling, use of paper, printing ink, etc.)

$0.97418 .547^{*}$

0.879 Fixed

$0.89124 .272 *$

$0.88820 .292 *$

$0.90622 .163 *$

$0.86716 .783^{*}$

$0.82216 .202^{*}$

0.950 Fixed

$0.93631 .053^{*}$

$0.82617 .491^{*}$

$0.96919 .038^{*}$

0.902 Fixed

$0.89123 .468^{*}$

$0.89123 .328 *$

$0.89520 .346^{*}$

$0.92013 .636^{*}$

0.749 Fixed

$0.89516 .651^{*}$

$0.89315 .074^{*}$

$0.91915 .640 *$

Customer perception of CSR $(C R=0.83 ; A V E=0.70)$

Customer-based ( $\alpha=0.960 ; \mathrm{CR}=0.96$; $\mathrm{AVE}=0.86$ )

CSR2.CUS1: in my branch they are honest with their customers

CSR2.CUS2: they make an effort to learn about my needs

CSR2.CUS3: they have mechanisms in place to resolve customers' complaints

CSR2.CUS4: they fulfill their contractual obligations with the customer

Society based $(\alpha=0.936 ; \mathrm{CR}=0.94 ; \mathrm{AVE}=0.79)$

CSR2.SOC1: they are aware of social and environmental issues

CSR2.SOC2: they are committed to ethical principles

CSR2.SOC3: the premises are adapted and accessible to everybody.

CSR2.SOC4: they are committed to improving the well-being of the neighborhood/city in which they operate

$0.84612 .391^{*}$

0.911 Fixed

$0.94233 .727 *$

$0.92827 .871 *$

$0.92830 .566^{*}$

$0.83010 .203^{*}$

0.829 Fixed

$0.90618 .497^{*}$

$0.90415 .690 *$

0.907 18.694*

Customer satisfaction ( $\alpha=0.933 ; C R=0.94 ; A V E=0.75)$

SAT1: my expectations have been met

SAT2: I am satisfied with the value for money offered

SAT3: I am satisfied with the service I have received

SAT4: I am satisfied with the company

SAT5: In general I am really satisfied

$0.89918 .402^{*}$

$0.87815 .112 *$

$0.72015 .920^{*}$

$0.90515 .404^{*}$

$0.90819 .132 *$

Customer trust $(\alpha=0.954 ; C R=0.95 ; A V E=0.81)$

TRU1: I trust the professional competence of the staff in my branch

$0.88622 .626 *$

$0.88722 .490^{*}$

$0.96128 .754^{*}$

$0.94327 .650 *$

$0.80716 .893^{*}$

(continued)
Table II.

Summary of the results after factor, reliability and validity analysis 
Customer engagement $(\alpha=0.928 ; C R=0.93 ; A V E=0.77)$

ENG1: I feel valued in my interactions with the branch

ENG2: I feel as though I have a personal relationship with my branch

ENG3: I consider that people in my branch are concerned about me as a person

Customer attitudinal loyalty $(\alpha=0.953 ; C R=0.95 ; A V E=0.84)$

LOY1: I try to visit my usual branch every time I need financial services

LOY2: I will try to continue with my usual branch in the coming years

$0.91718 .628^{*}$

$0.92219 .010^{*}$

LOY3: I will encourage my relatives and friends to become customers at this branch

Deleted

LOY4: as long as I continue to be treated in the same way I do not expect I will change my bank branch

$0.90116 .761^{*}$

LOY5: when I need a financial service I will come to this branch

$0.92018 .715^{*}$

Notes: Fit of the model: $\chi^{2}=1,032.327 ; \mathrm{df}=696, \chi^{2} / \mathrm{df}=1.483 ; \mathrm{NFI}=0.916 ; \mathrm{NNFI}=0.970 ; \mathrm{IFI}=0.976$;

Table II. $\mathrm{CFI}=0.975 ; \mathrm{RMR}=0.035 ; \mathrm{RMSEA}=0.041 . * p<0.01$

Cronbach's $\alpha(\alpha>0.7)$, and construct composite reliability (CR $>0.7)$ and analysis of variance extracted (AVE > 0.5) tests were ran (Churchill, 1979; Fornell and Larcker, 1981). A summary of the results of the factor and reliability tests is shown in Table II.

Convergent and discriminant validity were then analyzed. Convergent validity was verified by returning to the confirmatory factor analysis performed at the start of the process and observing the estimated value and significance of the correlations between the dimensions in the scales. These correlations were relatively high and significant and therefore sufficient guarantee of convergent validity. Table III shows the discriminant validity of the constructs considered, evaluated through AVE (Fornell and Larcker, 1981). When the square root of the AVE between each pair of factors is higher than the estimated correlation between those factors, as occurs here, discriminant validity is ratified.

\section{Analysis and findings}

After confirming the scales' validity and reliability, items that shared the same dimensions were averaged to form composite measures for the second order variables (Bandalos and Finney, 2001; Landis et al., 2000). Then, as with the validation of the scales, the hypotheses were tested using SEM with version 6.1 of the EQS multivariate software package (the covariance matrix is presented in Table IV). All the hypotheses were confirmed as shown in Table V, which also presents optimal model fit measures.

Our results thus confirm the importance of adopting socially responsible actions in bank branches, particularly in the present post-crisis context in which customers appear to be more aware of the social and ethical measures companies have introduced. Implementing

Table III.

Scale discriminant validity

\begin{tabular}{lllllll}
\hline & 1 & 2 & 3 & 4 & 5 & 6 \\
\hline 1. Supervisor perception of CSR & 0.92 & & & & & \\
2. Customer perception of CSR & $0.60^{*}$ & 0.84 & & & & \\
3. Customer satisfaction & $0.79^{*}$ & $0.64^{*}$ & 0.86 & & & \\
4. Customer trust & $0.75^{*}$ & $0.62^{*}$ & $0.60^{*}$ & 0.90 & & \\
5. Customer engagement & $0.72^{*}$ & $0.80^{*}$ & $0.67^{*}$ & $0.74^{*}$ & 0.88 & \\
6. Customer attitudinal loyalty & $0.77^{*}$ & $0.50^{*}$ & $0.74^{*}$ & $0.63^{*}$ & $0.58^{*}$ & 0.92
\end{tabular}

Notes: Below the diagonal: correlation estimated between the factors. Diagonal: square root of AVE. $* p<0.05$ 


\begin{tabular}{|c|c|c|c|c|c|c|c|c|c|c|c|c|c|}
\hline CSR1.1 & $\begin{array}{c}\text { CSR1.1 } \\
0.330\end{array}$ & CSR1.2 & CSR1.3 & CSR1.4 & CSR2.1 & CSR2.1 & SAT1 & SAT2 & SAT3 & SAT4 & SAT5 & TRU1 & $\begin{array}{r}\text { USK markeung } \\
\text { outcomes }\end{array}$ \\
\hline CSR1.2 & 0.272 & 0.444 & & & & & & & & & & & \\
\hline CSR1.3 & 0.266 & 0.386 & 0.478 & & & & & & & & & & \\
\hline CSR1.4 & 0.265 & 0.378 & 0.374 & 0.566 & & & & & & & & & \\
\hline CSR.2.1 & 0.144 & 0.233 & 0.223 & 0.257 & 0.631 & & & & & & & & \\
\hline CSR2.2 & 0.121 & 0.211 & 0.188 & 0.201 & 0.350 & 0.640 & & & & & & & \\
\hline SAT1 & 0.227 & 0.300 & 0.323 & 0.334 & 0.218 & 0.277 & 0.510 & & & & & & \\
\hline SAT2 & 0.203 & 0.286 & 0.291 & 0.318 & 0.290 & 0.309 & 0.413 & 0.519 & & & & & \\
\hline SAT3 & 0.272 & 0.361 & 0.367 & 0.384 & 0.222 & 0.196 & 0.329 & 0.304 & 0.500 & & & & \\
\hline SAT4 & 0.220 & 0.296 & 0.309 & 0.313 & 0.219 & 0.283 & 0.410 & 0.408 & 0.314 & 0.513 & & & \\
\hline SAT5 & 0.208 & 0.294 & 0.308 & 0.322 & 0.238 & 0.299 & 0.430 & 0.425 & 0.316 & 0.450 & 0.542 & & \\
\hline TRU1 & 0.314 & 0.397 & 0.450 & 0.476 & 0.282 & 0.267 & 0.392 & 0.339 & 0.433 & 0.372 & 0.350 & 1.001 & \\
\hline TRU2 & 0.280 & 0.356 & 0.389 & 0.441 & 0.302 & 0.305 & 0.338 & 0.290 & 0.355 & 0.321 & 0.294 & 0.847 & \\
\hline TRU3 & 0.330 & 0.430 & 0.478 & 0.522 & 0.412 & 0.325 & 0.384 & 0.352 & 0.453 & 0.379 & 0.357 & 0.859 & \\
\hline TRU4 & 0.311 & 0.430 & 0.484 & 0.520 & 0.410 & 0.311 & 0.377 & 0.370 & 0.449 & 0.368 & 0.357 & 0.868 & \\
\hline TRU5 & 0.226 & 0.333 & 0.347 & 0.410 & 0.418 & 0.277 & 0.302 & 0.338 & 0.353 & 0.294 & 0.307 & 0.634 & \\
\hline ENG1 & 0.256 & 0.317 & 0.336 & 0.348 & 0.263 & 0.279 & 0.350 & 0.330 & 0.304 & 0.332 & 0.328 & 0.458 & \\
\hline ENG2 & 0.235 & 0.326 & 0.348 & 0.391 & 0.496 & 0.387 & 0.324 & 0.351 & 0.334 & 0.324 & 0.352 & 0.491 & \\
\hline ENG3 & 0.247 & 0.335 & 0.378 & 0.382 & 0.357 & 0.332 & 0.351 & 0.345 & 0.328 & 0.342 & 0.349 & 0.485 & \\
\hline ENG4 & 0.219 & 0.330 & 0.336 & 0.393 & 0.420 & 0.350 & 0.336 & 0.357 & 0.306 & 0.325 & 0.358 & 0.413 & \\
\hline LOY1 & 0.255 & 0.308 & 0.331 & 0.319 & 0.175 & 0.224 & 0.328 & 0.308 & 0.321 & 0.319 & 0.309 & 0.451 & \\
\hline LOY2 & 0.241 & 0.314 & 0.344 & 0.320 & 0.179 & 0.231 & 0.344 & 0.328 & 0.332 & 0.351 & 0.324 & 0.447 & \\
\hline LOY4 & 0.255 & 0.334 & 0.357 & 0.316 & 0.181 & 0.296 & 0.363 & 0.337 & 0.331 & 0.351 & 0.347 & 0.450 & \\
\hline LOY5 & 0.243 & 0.324 & 0.367 & 0.346 & 0.241 & 0.276 & 0.357 & 0.344 & 0.343 & 0.368 & 0.367 & 0.513 & \\
\hline & TRU2 & TRU3 & TRU4 & TRU5 & ENG1 & ENG2 & ENG3 & ENG4 & LOY1 & LOY2 & LOY4 & LOY5 & \\
\hline CSR1.1 & & & & & & & & & & & & & \\
\hline CSR1.2 & & & & & & & & & & & & & \\
\hline CSR1.3 & & & & & & & & & & & & & \\
\hline CSR1.4 & & & & & & & & & & & & & \\
\hline CSR.2.1 & & & & & & & & & & & & & \\
\hline CSR2.2 & & & & & & & & & & & & & \\
\hline SAT1 & & & & & & & & & & & & & \\
\hline SAT2 & & & & & & & & & & & & & \\
\hline SAT3 & & & & & & & & & & & & & \\
\hline SAT4 & & & & & & & & & & & & & \\
\hline SAT5 & & & & & & & & & & & & & \\
\hline TRU1 & & & & & & & & & & & & & \\
\hline TRU2 & 0.970 & & & & & & & & & & & & \\
\hline TRU3 & 0.857 & 1.037 & & & & & & & & & & & \\
\hline TRU4 & 0.838 & 0.972 & 1.099 & & & & & & & & & & \\
\hline TRU5 & 0.644 & 0.729 & 0.793 & 0.882 & & & & & & & & & \\
\hline ENG1 & 0.467 & 0.496 & 0.488 & 0.383 & 0.611 & & & & & & & & \\
\hline ENG2 & 0.532 & 0.657 & 0.644 & 0.554 & 0.536 & 0.921 & & & & & & & \\
\hline ENG3 & 0.497 & 0.577 & 0.566 & 0.457 & 0.521 & 0.651 & 0.706 & & & & & & \\
\hline ENG4 & 0.449 & 0.572 & 0.574 & 0.490 & 0.473 & 0.737 & 0.587 & 0.818 & & & & & \\
\hline LOY1 & 0.394 & 0.404 & 0.386 & 0.285 & 0.339 & 0.276 & 0.341 & 0.271 & 0.558 & & & & \\
\hline LOY2 & 0.394 & 0.417 & 0.398 & 0.315 & 0.347 & 0.288 & 0.348 & 0.286 & 0.497 & 0.601 & & & \\
\hline LOY4 & 0.401 & 0.415 & 0.393 & 0.298 & 0.386 & 0.284 & 0.370 & 0.276 & 0.486 & 0.517 & 0.638 & & \\
\hline LOY5 & 0.450 & 0.491 & 0.494 & 0.365 & 0.381 & 0.357 & 0.390 & 0.359 & 0.502 & 0.516 & 0.531 & 0.633 & e matrix for \\
\hline \multicolumn{14}{|c|}{ Note: $N=225$} \\
\hline
\end{tabular}

these actions at the branch level will be decisive to building relational behaviors and attitudes with customers. Thus, the results show how customer perception of CSR has a highly positive and significant influence in generating the four customer relational outcomes considered: satisfaction ( $H 2: \lambda=0.847 ; t=9.837)$, trust $(H 3: \lambda=0.811 ; t=9.266)$, engagement $(H 4: \lambda=0.847 ; t=9.511)$ and attitudinal loyalty $(H 5: \lambda=0.797 ; t=9.104)$. 
In order to obtain high levels of this key factor, customer perception of CSR, the operational implementation of socially responsible actions and activities at the branch level is essential, and are reflected in the bank managers' perceptions of them (supervisors' perceptions of CSR). Indeed, it is the branch supervisors, not the managers further up in the organizational hierarchy, who are directly integrated in the context in which the customer relationship is managed, and therefore, they are responsible for effectively implementing and conveying the CSR practices in place in their branches. As the results of this study show, customers' perceptions of the CSR practices in their branch are clearly correlated with the supervisor's perception of them $(H 1: \lambda=0.894 ; t=8.946)$.

These results were also supported by the review of the $R^{2}$ obtained in testing the model, which allowed us to further examine the variance explained on each of the dependent variables of the model. Following Hair et al.'s (2011) rule of thumb that $R^{2}$ values of $0.75,0.50$ and 0.25 are substantial, moderate or weak, respectively, for the endogenous latent variables in the structural model, the five endogenous variables analyzed obtain at least acceptable levels ( $R^{2}$ satisfaction: $0.717 ; R^{2}$ trust: $0.657 ; R^{2}$ customer engagement: $0.717 ; R^{2}$ attitudinal loyalty: 0.636; $R^{2}$ customer perception of CSR: 0.799 ).

Hence, the relational outcomes for each branch are clearly related to the perception of CSR held by the branch manager, a relationship that is mediated by customer perception of CSR. To provide empirical support for this idea, in addition to the direct effects derived from the proposed relationship model, we calculated the indirect effects of supervisor perception of CSR on customer relational outcomes of CSR variables through the effects of customer perception of CSR (Aguinis et al., 2017). Table VI shows that the indirect effects of supervisor perception of CSR on satisfaction, trust, engagement and attitudinal loyalty through customer perception of $\operatorname{CSR}(\lambda=0.757, t=5.062 ; \lambda=0.725, t=4.971 ; \lambda=0.757$, $t=5.024$ and $\lambda=0.713 ; t=4.851$, respectively) are positive and significant.

\section{Conclusions}

\subsection{Theoretical implications}

This study aimed to answer the following question: What role do bank branch managers' perceptions of CSR play in generating satisfaction, trust, engagement

\begin{tabular}{llcccc}
\hline Hypotheses & Path & Parameter & $t$-value & Result & $R^{2}$ \\
\hline$H 1$ & $\begin{array}{l}\text { Supervisor perception of CSR } \rightarrow \text { customer perception } \\
\text { of CSR }\end{array}$ & 0.894 & $8.946^{*}$ & Supported & 0.799 \\
& Customer perception of CSR $\rightarrow$ satisfaction & 0.847 & $9.837^{*}$ & Supported & 0.717 \\
$H 2$ & Customer perception of CSR $\rightarrow$ trust & 0.811 & $9.266^{*}$ & Supported & 0.657 \\
$H 3$ & Customer perception of CSR $\rightarrow$ engagement & 0.847 & $9.511^{*}$ & Supported & 0.717 \\
$H 4$ & Customer perception of CSR $\rightarrow$ attitudinal loyalty & 0.797 & $9.104^{*}$ & Supported & 0.636
\end{tabular}

Table V.
Summary results of the structural model

Notes: Fit of the model: $\chi^{2}=311.242, \mathrm{df}=181, \chi^{2} / \mathrm{df}=1.719 ; \mathrm{NFI}=0.950 ; \mathrm{NNFI}=0.970 ; \mathrm{IFI}=0.981$; $\mathrm{CFI}=0.980 ; \mathrm{RMR}=0.040 ; \mathrm{RMSEA}=0.051 . * p<0.01$

\begin{tabular}{lcr}
\hline Path & Parameter & $t$-value \\
\hline Supervisor perception of CSR $\rightarrow$ satisfaction & 0.757 & $5.062^{*}$ \\
Supervisor perception of CSR $\rightarrow$ trust & 0.725 & $4.971^{*}$ \\
Supervisor perception of CSR $\rightarrow$ engagement & 0.757 & $5.024^{*}$ \\
Supervisor perception of CSR $\rightarrow$ Attitudinal loyalty & 0.713 & $4.851^{*}$ \\
Note: $* x<0.01$ & & \\
\hline
\end{tabular}

Indirect effects derived from the structural model

Note: ${ }^{*} p<0.01$ 
and loyalty among the branch's customers? The question was further divided into CSR marketing two parts:

$R Q 1$. How do bank branch managers' perceptions of CSR influence the bank customers' perceptions of CSR?

RQ2. How do the bank customers' perceptions of CSR influence their satisfaction, trust, engagement and loyalty?

With regard to the first part, customers' perceptions of CSR vary across bank branches and are greatly influenced by the perception of CSR held by the manager of the branch. The manager's perception of CSR affects the balance he or she strikes between defending the company's interests (shareholders) on the one hand, and those of other key stakeholders such as customers, society and employees, on the other. Branch managers must efficiently combine the pursuit of profits for the bank with a responsible human resources policy for the branch's internal stakeholders: its employees. He or she must also attend to the interests of external stakeholders, the branch's customers, and engage with the local community through socially responsible actions. This balancing of interests by the manager (which gives the branch its own personality) is transmitted to customers, who evaluate how their own interests are respected as well as the bank's involvement with the local community. The way a bank's CSR strategy is deployed will therefore vary from one branch to another (Maignan et al., 2005), which highlights the key role played by the branch manager.

Regarding the second part of the question, the relational outcomes (satisfaction, trust, engagement and loyalty) of the branch depend on how the customers perceive CSR in their particular branch. Relationship marketing advocates constructing long-term relationships with customers, for which customers must be satisfied, trusted, engaged and loyal. This study shows that customers' perceptions of the bank's CSR policy are central to achieving optimum relational outcomes and securing customers' trust.

The response to the research question, therefore, is that branch managers' perceptions of CSR have a decisive impact on the relational outcomes in their branch, thus highlighting the key role played by this intermediary figure, who must adopt and internalize the organization's CSR strategy and implement it in their own branch context, while balancing the interests of shareholders with those of other key stakeholders (customers, employees and society).

These conclusions provide some innovative contributions to the CSR and marketing literature. First, they reveal the differences within the same organization in the way its CSR strategy is implemented. These differences should be taken into account in organizations that deploy their strategy through a network of offices or branches to attend the public. Second, intermediary figures or supervisors are shown to have a key role in ensuring the organization's CSR strategy is effective, since it is these managers who interpret and lend credibility to the policies designed at higher levels of the organizational hierarchy. Third, the study emphasizes the importance of customers' perception of CSR in achieving the main outcomes of relationship marketing (satisfaction, trust, engagement and loyalty). This finding provides strong support for CSR investment by organizations. Fourth, the methodology applied in the study is innovative in its construction of dyads in which the branch is the unit of analysis, enabling a comparison between the manager's perceptions of CSR with that of five customers from the same branch. Fifth, the findings add to our knowledge of a particularly relevant sector in the recent economic crisis, namely, the retail banking industry, which has had to work hard to re-build credibility amongst its customers, committing to CSR in its endeavors to do so.

\subsection{Managerial implications}

The results highlight the importance of adopting socially responsible actions not only in the bank as a whole, but also in individual branches. The governance mechanisms used to 
align the branches with the bank's strategic objectives generally center on financial outcomes, such that the economic rewards paid to branch employees are directly related to their achievement of a series of financial outcomes. Given the banking industry's current strategic interest in CSR, one initial proposal would be to include CSR indicators in the incentive systems applied in the branches. This would give the branch manager and his or her team an economic incentive to implement the corporate CSR strategy. Our second proposal, which complements the first, is to extend the incentives system to include specific monitoring and control of CSR-related aspects. The CSR strategy should be included on the agenda of branch level and territory level control and monitoring meetings as a matter of routine.

To support the two governance mechanisms proposed by agency theory, we believe it is important to strengthen CSR values in the organizational culture. To this end, improvement in the banking industry can be achieved in various ways. First, staff training in aspects of CSR should be increased so the branch manager and his or her team are able to recognize the importance of this aspect, thereby empowering them to implement local CSR initiatives (Lindgreen and Swaen, 2010). Second, many financial institutions delegate their CSR policy to foundations to which they allocate considerable economic resources. This strategy, however, impedes the implementation of local CSR initiatives by branch offices because no specific budget or administrative support is available for this purpose. Foundations should be more sensitive to local contexts and provide the support needed at the branch level. Third, greater efforts should be made to extend interpersonal communication with customers. Communication about CSR issues is usually channeled through the bank's CSR report and website. However, it is questionable whether this information has any impact on stakeholders other than shareholders and the board of directors. Greater efforts should therefore be made in internal and external communication to publicize the financial institution's CSR work. Fourth, the CSR strategy should permeate the whole of the bank's hierarchy. Branch offices are grouped geographically in a hierarchical structure that covers their entire reference market. CSR activities must also be promoted by those above the branch managers in the hierarchy, since branch offices will find it difficult to implement such initiatives at the local level if territorial managers are not aligned with the CSR strategy. Finally, branch offices could publicize their social and environmental initiatives not only through audiovisual media in the branches, but also by encouraging customerfacing staff to personally explain the branch's CSR activities.

\subsection{Limitations and future research}

The study has certain limitations that should be noted. The first concerns the sample, which was taken from a single bank in the same country (Spain). Although reflecting a specific reality, this is an illustrative example of a country where the great recession has had a severe impact and where trust in its financial sector has been heavily eroded. New studies could usefully test the relationships posited in other banks and international contexts, which would favor the generalization of our results.

Second, this study is based on data gathered from a single interviewee, the bank manager, in each branch in the sample. This raises the question of whether one person's responses accurately reflect the views of all the branch staff (Barnes, 1984). In the case of organizational units - the branch in this study - with an average of between five and six employees, the literature considers the unit manager to be the most competent person to speak honestly on behalf of the unit (Weerawardena, 2003; Davidsson, 2004). In our study, the manager has the most comprehensive knowledge about the branch's characteristics, strategies and results (Hambrick, 1981), is familiar with all aspects related to its operations, influences strategy management and plays a fundamental decision-making role (Miller and Toulouse, 1986). 
The third limitation is the number of customers interviewed in each branch (five), although this does align with methodological recommendations in the literature (George and Bettenhausen, 1990; Yoon and Suh, 2003). Nevertheless, the average number of customers interviewed per branch should be increased to improve the accuracy of the results.

Fourth, the type of customers analyzed should be taken into account since a growing number of customers now carry out all their banking online and are less likely to visit their branch. A useful future research line would be to explore how the CSR strategy is implemented in online environments where neither managers nor employees are present to co-create the service.

Finally, the transversal data used in the study may be regarded as a limitation when drawing causal inferences. Future studies could use longitudinal data to explore the effects on the performance variable posited in our research. Similarly, new qualitative studies are needed at various levels in order to take into account the responses of agents from different levels of the bank hierarchy. Taking a quantitative approach, SEM models could be used to apply data in dyads to analyze the causal relationships between factors associated with agents at different levels in the hierarchy according to levels of responsibility (top managers, branch manager and branch employees). Such studies may reveal similarities in perceptions of the strategic and operational factors associated with CSR at different hierarchical levels.

\section{References}

Aguinis, H. and Glavas, A. (2012), "What we know and don't know about corporate social responsibility: a review and research agenda", Journal of Management, Vol. 38 No. 4, pp. 932-968.

Aguinis, H., Edwards, J.R. and Bradley, K.J. (2017), "Improving our understanding of moderation and mediation in strategic management research", Organizational Research Methods, Vol. 20 No. 4, pp. 665-685.

Andriof, J. and Waddock, S. (2002), "Unfolding stakeholder engagement", in Andriof, J., Waddock, S., Husted, B. and Sutherland, S. (Eds), Unfolding Stakeholder Thinking: Theory, Responsibility and Engagement, Greenleaf, Sheffield, pp. 19-42.

Ashraf, S., Ilyas, R., Imtiaz, M. and Tahir, H.M. (2017), "Impact of CSR on customer loyalty: putting customer trust, customer identification, customer satisfaction and customer commitment into equation-a study on the banking sector of Pakistan”, International Journal of Multidisciplinary and Current Research, Vol. 5 No. 5, pp. 1362-1372.

Aurier, P. and N'Goala, G. (2010), "The differing and mediating roles of trust and relationship commitment in service relationship maintenance and development", Journal of the Academy of Marketing Science, Vol. 38 No. 3, pp. 303-325.

Bagozzi, R.P. and Youjae, Y. (1988), "On the evaluation of structural equation models”, Journal of the Academy of Marketing Science, Spring, Vol. 16 No. 1, pp. 74-94.

Bandalos, D.L. and Finney, S.J. (2001), "Item parceling issues in structural equation modeling", New Developments and Techniques in Structural Equation Modeling, Routledge Taylor and Francis Group (Lawrence Erlbaum Associates), Mahwah, NJ, pp. 269-296.

Barnes, J.H. (1984), "Cognitive biases and their impact on strategic planning”, Strategic Management Journal, Vol. 5 No. 2, pp. 129-138.

Barnett, M.L. (2007), "Stakeholder influence capacity and the variability of financial returns to corporate social responsibility", Academy of Management Review, Vol. 32 No. 3, pp. 794-816.

Batko, J.J. (1976), "On various intraclass correlation reliability coefficients", Psychological Bulletin, Vol. 83 No. 5, pp. $762-765$.

Berger, I.E., Cunningham, P.M. and Drumwright, M.E. (2006), "Identity identification and relationship through social alliances", Journal of the Academy of Marketing Sciences, Vol. 34 No. 2, pp. 128-137. 
Berman, S.L., Wicks, A.C., Kotha, S. and Jones, T.M. (1999), "Does stakeholder orientation matter? The relationship between stakeholder management models and firm financial performance", Academy of Management Journal, Vol. 42 No. 5, pp. 488-506.

Bhandarker, A. (2003), "Building corporate transformation new HR agenda", Vision, Vol. 7 No. 2, pp. 1-23.

Bhattacharya, C.B. and Sen, S. (2003), "Consumer-company identification: a framework for understanding consumers' relationships with companies", Journal of Marketing, Vol. 67 No. 2, pp. 76-88.

Bhattacharya, C.B., Korschun, D. and Sen, S. (2009), "Strengthening stakeholder-company relationships through mutually beneficial corporate social responsability initiatives", Journal of Business Ethics, Vol. 85 No. S2, pp. 257-272.

Bhattacharya, C.B., Sen, S. and Korschun, D. (2008), "Using corporate social responsibility to win the war for talent”, MIT Sloan Management Review, Vol. 49 No. 2, pp. 37-44.

Bhattacharya, C.B., Sen, S. and Korschun, D. (2011), "Maximizing ROI from corporate responsibility", The European Financial Review, Vols 11/12 No. 6, pp. 48-50.

Blasco, L. (2014), "Los procesos de co-creación y el engagement del cliente: un análisis empírico en medios interactivos", doctoral dissertation, Universidad de Zaragoza, Zaragoza.

Bloemer, J.M.M. and Odekerken, G. (2002), "Store satisfaction and store loyalty explained by customerand store related factors", Journal of Consumer Satisfaction, Dissatisfaction and Complaining Behaviour, Vol. 15 No. 1, pp. 68-80.

Brammer, S., Millington, A. and Rayton, B. (2007), "The contribution of corporate social responsibility to organizational commitment", International Journal of Human Resource Management, Vol. 18 No. 10 , pp. 1701-1719.

Bravo, R., Matute, J. and Pina, J.M. (2012), "Corporate social resonsibility as a vehicle to reveal the corporate identity: a study on the websites of Spanish financial entities", Journal of Business Ethics, Vol. 107 No. 2, pp. 129-146.

Brislin, R.W. (1970), "Back translation for the cross-cultural research", Journal of Cross-Cultural Psychology, Vol. 1 No. 3, pp. 185-216.

Brodie, R.J., Hollebeek, L.D., Jurić, B. and Ilić, A. (2011), "Customer engagement: conceptual domain, fundamental propositions, and implications for research", Journal of Service Research, Vol. 14 No. 3, pp. 252-271.

Camarero, M.C., Gutiérrez, J. and San Martín, S. (2005), "The impact of customer relationship marketing on the firm performance: a Spanish case", Journal of Services Marketing, Vol. 19 No. 4, pp. 234-244.

Cambra-Fierro, J., Melero-Polo, I. and Sese, F.J. (2016), "Can complaint-handling efforts promote customer engagement?", Service Business, Vol. 10 No. 4, pp. 847-866.

Carroll, A.B. (2006), “The four faces of corporate citizenship”, Business and Society Review, Vols 100/101 No. 1, pp. 1-7.

Carroll, A.B. (2015), "Corporate social responsability. the center-piece of competing and complementary frameworks", Organizational Dynamics, Vol. 44 No. 87, pp. 87-96.

Chahal, H. and Dutta, K. (2015), "Measurement and impact of customer experience in banking sector", Decision, Vol. 42 No. 1, pp. 57-70.

Chahal, H. and Sharma, R.D. (2006), "Implications of corporate social responsibility on marketing performance: a conceptual framework", Journal of Services Research, Vol. 6 No. 1, pp. 205-216.

Cheung, C.M.K., Shen, X.L., Lee, Z.W.Y. and Chan, T.K.H. (2015), "Promoting sales of online games through customer engagement”, Electronic Commerce Research and Applications, Vol. 14 No. 4, pp. 241-250.

Chomvilailuk, R. and Butcher, K. (2013), "The effect of CSR knowledge on customer liking across cultures", International Journal of Bank Marketing, Vol. 31 No. 2, pp. 98-114. 
Churchill, G.A. Jr (1979), “A paradigm for developing better measures in marketing”, Journal of CSR marketing Marketing Research, Vol. 16 No. 1, pp. 64-73.

Daub, C.H. and Ergenzinger, R. (2005), "Enabling sustainable management through a new multidisciplinary concept of customer satisfaction", European Journal of Marketing, Vol. 39 Nos 9/10, pp. 998-1012.

Davidsson, P. (2004), Researching on Entrepreneurship, Springer, New York, NY.

Davis, R.E., Couper, M.P., Janz, N.K., Caldwell, C.H. and Resnicow, K. (2010), "Interviewer effects in public health surveys", Health Education Research, Vol. 25 No. 1, pp. 14-26.

Dimitriadis, S., Kouremenos, A. and Kyrezis, N. (2011), "Trust-based segmentation. Preliminary evidence from technology-enabled bank channels", International Journal of Bank Marketing, Vol. 29 No. 1, pp. 5-31.

Du, S., Bhattacharya, C.B. and Sen, S. (2007), "Convergence of interests - cultivating consumer trust through corporate social initiatives", Advances in Consumer Research, Vol. 34 No. 6, p. 687.

Du, S., Bhattacharya, C.B. and Sen, S. (2015), "Corporate social responsibility, multi-faceted jobproducts, and employee outcomes", Journal of Business Ethics, Vol. 131 No. 2, pp. 319-355.

Eisenhardt, K.M. (1989), "Agency theory: an assessment and review”, Academy of Management Review, Vol. 14 No. 1, pp. 57-74.

El Akremi, A., Gond, J.P., Swaen, V., De Roeck, K. and Igalens, J. (2018), "How do employees perceive corporate responsibility? Development and validations of a multidimensional corporate stakeholder responsibility scale", Journal of Management, Vol. 44 No. 2, pp. 619-657.

El-Manstrly, D., Paton, T., Veloutsou, C. and Moutinho, L. (2011), "An empirical investigation of the relative effect of trust and switching costs on service loyalty in the UK retail banking industry", Journal of Financial Services Marketing, Vol. 16 No. 2, pp. 101-110.

Farrell, M.A. and Oczkowski, E. (2009), "Service worker customer orientation, organisation/job fit and perceived organisational support", Journal of Strategic Marketing, Vol. 17 No. 2, pp. 149-167.

Fatma, M., Rahman, Z. and Khan, I. (2015), "Building company reputation and brand equity through CSR: the mediating role of trust", International Journal of Bank Marketing, Vol. 33 No. 6, pp. 840-856.

Fornell, C. and Larcker, D.F. (1981), "Evaluating structural equation models with unobservable variables and measurement error", Journal of Marketing Research, Vol. 18 No. 1, pp. 39-50.

Freeman, R.E. (1984), Strategic Management: A Stakeholder Approach, Pittman, Boston, MA.

Friedrich, T.L., Byrne, C.L. and Mumford, M.D. (2009), "Methodological and theoretical considerations in survey research", The Leadership Quarterly, Vol. 20 No. 2, pp. 57-60.

García, M.P., Herrero, A. and Rodríguez, I. (2005), "Influence of corporate social responsability on loyalty and valuation of services", Journal of Business Ethics, Vol. 61 No. 4, pp. 369-385.

George, J.M. and Bettenhausen, K. (1990), "Understanding prosocial behavior, sales performance, and turnover: a group-level analysis in a service context”, Journal of Applied Psychology, Vol. 75 No. 6, pp. 698-709.

Glick, W.H. (1985), "Conceptualizing and measuring organizational and psychological climate: pitfalls in multilevel research", Academy of Management Review, Vol. 10 No. 3, pp. 601-616.

Greening, D.W. and Turban, D.B. (2000), "Corporate social performance as a competitive advantage in attracting a quality workforce", Business and Society, Vol. 39 No. 3, pp. 254-280.

Groves, R.M. (2004), Survey Errors and Survey Costs, John Wiley \& Sons, Hoboken, NJ.

Ha, H.Y., Akamavi, R.K., Kitchen, P.J. and Janda, S. (2014), "Exploring key antecedents of purchase intentions within different services", Journal of Services Marketing, Vol. 28 No. 7, pp. 595-606.

Hair, J.F., Ringle, C.M. and Sarstedt, M. (2011), "PLS-SEM: indeed a silver bullet”, Journal of Marketing Theory and Practice, Vol. 19 No. 2, pp. 139-151.

Hair, J.F., Black, W.C., Babin, B.J. and Anderson, R.E. (2010), Multivariate Data Analysis, Prentice Hall, Upper Saddle River, NJ. 
Hambrick, D.C. (1981), "Strategic awareness within top management teams", Strategic Management Journal, Vol. 2 No. 3, pp. 263-279.

He, H. and Li, Y. (2011), "CSR and service brand: the mediating effect of brand identification and moderating effect of service quality", Journal of Business Ethics, Vol. 100 No. 4, pp. 673-688.

Herrbach, O., Mignonac, K. and Gatignon, A.L. (2004), "Exploring the role of perceived external prestige in managers' turnover intentions", The International Journal of Human Resource Management, Vol. 15 No. 8, pp. 1390-1407.

Hollebeek, L. (2011), "Exploring customer brand engagement: definition and themes", Journal of Strategic Marketing, Vol. 19 No. 7, pp. 555-573.

Hollebeek, L. and Chen, T. (2014), "Exploring positively-versus negatively-valenced brand engagement: a conceptual model", Journal of Product and Brand Management, Vol. 23 No. 1, pp. 62-74.

Hox, J.J. (1994), "Hierarchical regression models for interviewer and respondent effects", Sociological Methods \& Research, Vol. 22 No. 3, pp. 300-318.

Jaiyeoba, H.B., Adewale, A.A. and Quadry, M.O. (2018), “Are Malaysian Islamic banks; corporate social responsibilities effective? A stakeholders' view”, International Journal of Bank Marketing, Vol. 36 No. 1, pp. 111-125.

James, L.R. (1982), "Aggregation bias in estimates of perceptual agreement”, Journal of Applied Psychology, Vol. 67 No. 2, pp. 219-229.

Jensen, M.C. and Meckling, W.H. (1976), "Theory of the firm: managerial behavior, agency costs and ownership structure", Journal of Financial Economics, Vol. 3 No. 4, pp. 305-360.

Jöreskog, K. and Sörbom, D. (1993), LISREL 8: Structural Equation Modeling with the SIMPLIS Command Language, Scientific Software International, Chicago, IL.

Kaler, J. (2009), “An optimally viable version of stakeholder theory”, Journal of Business Ethics, Vol. 86 No. 3, pp. 297-312.

Kantsperger, R. and Kunz, W.H. (2010), "Consumer trust in service companies: a multiple mediating analysis", Managing Service Quality, Vol. 20 No. 1, pp. 4-25.

Khan, H.U.A., Azizul, I.M., Kayeser, F.J. and Ahmed, K. (2011), "Corporate sustainability reporting of major commercial banks in line with GRI: Bangladesh evidence", Social Responsibility Journal, Vol. 7 No. 3, pp. 347-362.

Khan, Z., Ferguson, D. and Pérez, A. (2015), "Customer responses to CSR in the Pakistani banking industry”, International Journal of Bank Marketing, Vol. 33 No. 4, pp. 471-493.

Kilic, M. (2016), "Online corporate social responsibility (CSR) disclosure in the banking industry: evidence from Turkey”, International Journal of Bank Marketing, Vol. 34 No. 4, pp. 550-569.

Kim, H.R., Lee, M., Lee, H.T. and Kim, N.M. (2010), "Corporate social responsibility and employeecompany identification”, Journal of Business Ethics, Vol. 95 No. 4, pp. 557-569.

Klaus, P., Gorgoglione, M., Buonamassa, D., Panniello, U. and Nguyen, B. (2013), “Are you providing the 'right' customer experience? The case of Banca Popolare di Bari”, International Journal of Bank Marketing, Vol. 31 No. 7, pp. 506-528.

Krasodomska, J. (2015), "CSR disclosures in the banking industry: empirical evidence from Poland", Social Responsibility Journal, Vol. 11 No. 3, pp. 406-423.

Kumar, V., Pozza, I.D. and Ganesh, J. (2013), "Revisiting the satisfaction-loyalty relationship: empirical generalizations and directions for future research", Journal of Retailing, Vol. 89 No. 3, pp. 246-262.

Lamberti, L. and Lettieri, E. (2009), "CSR practices and corporate strategy: evidence from a longitudinal case study", Journal of Business Ethics, Vol. 87 No. 2, pp. 153-168.

Landis, R.S., Beal, D.J. and Tesluk, P.E. (2000), "A comparison of approaches to forming composite measures in structural equation models", Organizational Behavioral Research, Vol. 3 No. 2, pp. 186-207. 
Larson, B.V., Flaherty, K.E., Zablah, A.R., Brown, T.J. and Wiener, J.L. (2008), "Linking cause-related marketing to sales force responses and performance in a direct selling context", Journal of the Academy of Marketing Science, Vol. 36 No. 2, pp. 271-277.

Lin, C., Chen, S., Chiu, C. and Lee, W. (2011), "Understanding purchase intention during product-harm crises: moderating effects of perceived corporate ability and corporate social responsibility", Journal of Business Ethics, Vol. 102 No. 3, pp. 455-471.

Lindgreen, A. and Swaen, V. (2010), "Corporate social responsibility", International Journal of Management Reviews, Vol. 12 No. 1, pp. 1-7.

Liu, M.T., Wong, I.A., Shi, G., Chu, R. and Brock, J.L. (2014), "The impact of corporate social responsibility (CSR) performance and perceived brand quality on customer-based brand preference", Journal of Services Marketing, Vol. 28 No. 3, pp. 181-194.

Luo, X. and Bhattacharya, C.B. (2006), "Corporate social responsibility, customer satisfaction, and market value", Journal of Marketing, Vol. 70 No. 4, pp. 1-18.

McDonald, L. and Rundle-Thiele, S. (2008), "Corporate social responsibility and bank customer satisfaction: a research agenda", International Journal of Bank Marketing, Vol. 26 No. 3, pp. 170-182.

Maignan, I. and Ferrell, O.C. (2001), "Corporate citizenship as a marketing instrument-concepts, evidence and research directions", European Journal of Marketing, Vol. 35 Nos 3/4, pp. 457-484.

Maignan, I. and Ferrell, O.C. (2004), "Corporate social responsibility and marketing: an integrative framework", Journal of the Academy of Marketing Science, Vol. 32 No. 1, pp. 3-19.

Maignan, I., Ferrell, O.C. and Ferrell, L. (2005), "A stakeholder model for implementing social responsibility in marketing”, European Journal of Marketing, Vol. 39 Nos 9/10, pp. 956-977.

Mandhachitara, R. and Poolthong, Y. (2011), "A model of customer loyalty and corporate social responsibility”, Journal of Services Marketing, Vol. 25 No. 2, pp. 122-133.

Martínez, P. and del Bosque, I.R. (2013), "CSR and customer loyalty: the roles of trust, customer identification with the company and satisfaction", International Journal of Hospitality Management, Vol. 35 No. 1, pp. 89-99.

Medlin, B. and Green, K.W. (2009), "Enhancing performance through goal setting, engagement and optimism”, Industrial Management \& Data Systems, Vol. 109 No. 7, pp. 943-956.

Miller, D. and Toulouse, J.M. (1986), "Chief executive personality and corporate strategy and structure in small firms", Management Science, Vol. 32 No. 1, pp. 1389-1409.

Mitchell, R.K., Agle, B.R. and Wood, D.J. (1997), "Toward a theory of stakeholder identification and salience: defining the principle of who and what really counts", Academy of Management Review, Vol. 22 No. 4, pp. 853-886.

Mithas, S., Krishnan, M.S. and Fornell, C. (2005), "Why do customer relationship management applications affect customer satisfaction?”, Journal of Marketing, Vol. 69 No. 4, pp. 201-209.

Narwal, M. (2007), “CSR initiatives of Indian banking industry”, Social Resonsibility Journal, Vol. 3 No. 4, pp. 49-60.

Oh, W.Y., Chang, Y.K. and Kim, T.Y. (2018), "Complementary or substitute effects? Corporate governance mechanisms and corporate social responsibility", Journal of Management, Vol. 44 No. 7, pp. 2716-2739.

Oliver, R.L. (1999), “Whence consumer loyalty?”, Journal of Marketing, Vol. 63 No. 1, pp. 33-44.

Pansari, A. and Kumar, V. (2017), "Customer engagement: the construct, antecedents, and consequences", Journal of the Academy of Marketing Science, Vol. 45 No. 3, pp. 294-311.

Peloza, J. (2009), "The challenge of measuring financial impacts from investments in corporate social performance", Journal of Management, Vol. 35 No. 6, pp. 1518-1541.

Pérez, A. and Rodríguez, I. (2012), "The role of CSR in the corporate identity of banking service providers", Journal of Business Ethics, Vol. 108 No. 2, pp. 145-166. 
Pérez, A. and Rodríguez, I. (2013), "Measuring CSR image: three studies to develop and to validate a reliable measurement tool", Journal of Business Ethics, Vol. 11 No. 8, pp. 265-286.

Pérez, A. and Rodríguez, I. (2014), "Customer CSR expectations in the banking industry", International Journal of Bank Marketing, Vol. 32 No. 3, pp. 223-244.

Pérez, A. and Rodríguez, I. (2017), "Personal traits and customer responses to CSR perceptions in the banking sector", International Journal of Bank Marketing, Vol. 35 No. 1, pp. 128-146.

Pérez, A., García, M.M. and Rodríguez, I. (2013), "The effect of corporate associations on consumer behavior”, European Journal of Marketing, Vol. 47 No. 1, pp. 218-238.

Peterson, D.K. (2004), "The relationship between perceptions of corporate citizenship and organizational commitment", Business and Society, Vol. 43 No. 3, pp. 296-319.

Pirsch, J., Gupta, S. and Grau, S.L. (2007), "A framework for understanding corporate social responsibility programs as a continuum: an exploratory study", Journal of Business Ethics, Vol. 70 No. 2, pp. 125-140.

Podsakoff, P.M., Mackenzie, S.B., Lee, J.Y. and Podsakoff, N.P. (2003), "Common method biases in behavioral research: a critical review of the literature and recommended remedies", Journal of Applied Psychology, Vol. 88 No. 5, pp. 879-903.

Pratihari, S.K. and Uzma, S.H. (2018), "Corporate social identity: an analysis of the Indian banking sector", International Journal of Bank Marketing, Vol. 36 No. 7, pp. 1248-1284.

Ramus, C.A. and Steger, U. (2000), "The roles of supervisory support behaviors and environmental policy in employee 'ecoinitiatives' at leading-edge European companies", Academy of Management Journal, Vol. 43 No. 4, pp. 605-626.

Rego, A., Leal, S. and Cunha, M.P. (2011), "Rethinking the employees' perceptions of corporate citizenship dimensionalization”, Journal of Business Ethics, Vol. 104 No. 2, pp. 207-218.

Rodrigo, P. and Arenas, D. (2008), "Do employees care about CSR programs? A typology of employees according to their attitudes", Journal of Business Ethics, Vol. 83 No. 2, pp. 265-283.

Rupp, D.E., Ganapathi, J., Aguilera, R.V. and Williams, C.A. (2006), "Employee reactions to corporate social responsibility: an organizational justice framework", Journal of Organizational Behavior, Vol. 27 No. 4, pp. 537-543.

Saeidi, S.P., Sofian, S., Saeidi, P., Saeidi, S.P. and Saaeidi, S.A. (2015), "How does corporate social responsibility contribute to firm financial performance? The mediating role of competitive advantage, reputation, and customer satisfaction”, Journal of Business Research, Vol. 68 No. 2, pp. 341-350.

Saks, A.M. and Gruman, J.A. (2014), "What do we really know about employee engagement?", Human Resource Development Quarterly, Vol. 25 No. 2, pp. 155-182.

Schneider, B. and Bowen, D.E. (1985), "Employee and customer perceptions of services in banks: replication and extension", Journal of Applied Psychology, Vol. 70 No. 3, pp. 423-433.

Sprott, D., Czellar, S. and Spangenberg, E. (2009), "The importance of a general measure of brand engagement on market behavior: development and validation of a scale", Journal of Marketing Research, Vol. 46 No. 1, pp. 92-104.

Stanaland, A.J., Lwin, M.O. and Murphy, P.E. (2011), "Consumer perceptions of the antecedents and consequences of corporate social responsibility", Journal of Business Ethic, Vol. 102 No. 1, pp. 47-55.

Steenkamp, J.B.E.M. and Van Trijp, H.C.M. (1991), "The use of LISREL in validating marketing constructs", International Journal of Research in Marketing, Vol. 8 No. 4, pp. 283-299.

Sureshchandar, G.S., Rajendran, C. and Anantharaman, R. (2002), "Determinants of customer-perceived service quality: a confirmatory factor analysis approach", Journal of Services Marketing, Vol. 16 No. 1, pp. 9-34.

Sureshchandar, G.S., Rajendran, C. and Kamalanabhan, T.J. (2001), "Customer perceptions of service quality: a critique", Total Quality Management, Vol. 12 No. 1, pp. 111-124. 
Swaen, V. and Chumpitaz, R.C. (2008), "Impact of corporate social responsibility on consumer trust", Recherché et Applications en Marketing, English Edition, Vol. 23 No. 4, pp. 7-33.

Tinker, M. and Banner, L. (2017), "Consumer purchasing decisions in financial institutions: corporate social responsibility strategy", GSTF Journal of Business Review, Vol. 5 No. 2, pp. 1-6.

Tortosa, V., Llorens, J., Moliner, M.A. and Sánchez, J. (2015), "The influence of internal market orientation on external outcomes", Journal of Service Theory and Practice, Vol. 25 No. 4, pp. 486-523.

Turker, D. (2009), "Measuring corporate social responsibility: a scale development study", Journal of Business Ethics, Vol. 85 No. 4, pp. 411-427.

Valentine, S. and Fleischman, G. (2008), "Ethics programs, perceived corporate social responsibility and job satisfaction”, Journal of Business Ethics, Vol. 77 No. 2, pp. 159-172.

Van Doorn, J., Lemon, K.N., Mittal, V., Nass, S., Pick, D., Pirner, P. and Verhoef, P.C. (2010), “Customer engagement behavior: theoretical foundations and research directions", Journal of Service Research, Vol. 13 No. 3, pp. 253-266.

Verhoef, P.C., Reinartz, W.J. and Krafft, M. (2010), "Customer engagement as a new perspective in customer management”, Journal of Service Research, Vol. 13 No. 3, pp. 247-252.

Verleye, K. (2015), "The co-creation experience from the customer perspective: its measurement and determinants", Journal of Service Management, Vol. 26 No. 2, pp. 321-342.

Walsh, G. and Bartikowski, B. (2013), "Exploring corporate ability and social responsibility associations as antecedents of customer satisfaction cross-culturally", Journal of Business Research, Vol. 66 No. 8, pp. 989-995.

Weerawardena, J. (2003), "Exploring the role of market learning capability in competitive strategy", European Journal of Marketing, Vol. 37 Nos 3/4, pp. 407-429.

Ye, J., Marinova, D. and Singh, J. (2007), "Strategic change implementation and performance loss in the front lines", Journal of Marketing, Vol. 71 No. 4 pp. 156-171.

Yoon, M.H. and Suh, J. (2003), "Organizational citizenship behaviors and service quality as external effectiveness of contact employees”, Journal of Business Research, Vol. 56 No. 8, pp. 597-611.

\section{Further reading}

Bhattacharya, C.B. and Sen, S. (2004), "Doing better at doing good: when, why, and how consumers respond to corporate social initiatives", California Management Review, Vol. 47 No. 1, pp. 9-24.

\section{Corresponding author}

Miguel Angel Moliner can be contacted at: amoliner@uji.es

For instructions on how to order reprints of this article, please visit our website: 